\title{
"The Most Dangerous Drug": Images of African- Americans and Cocaine Use in the Progressive Era ${ }^{1}$
}

\section{Catherine Carstairs}

On 8 February, 1914, the New York Times published a full-page article entitled "Negro Cocaine 'Fiends' Are a New Menace." Under a picture of the stern and respectable-looking white author, Edward Huntington Williams, M.D., the article's subtitle proclaimed: "Murder and Insanity Increasing Among Lower Class Blacks Because They Have Taken to 'Sniffing."' Williams claimed that crazed cocaine users had killed nine men in Mississippi on a single occasion. $\mathrm{He}$ declared: "there is no escaping the conviction that drug taking has become a race menace in certain regions south of the line." Further, Williams asserted that blacks who took cocaine improved their marksmanship, causing incidents such as that of the "cocaine nigger" near Asheville, North Carolina, who killed five men, using only one bullet for each. Even worse, he claimed, cocaine provided a "temporary immunity to shock - a resistance to the 'knock-down' effects of fatal wounds." Thus when the chief of police of Asheville tried to kill another black man who was "running amuck" in a cocaine frenzy, he fired directly at his heart. Although the bullet hit its mark, it had no impact. He stated that police officers in the South, afraid of the "increased vitality of the cocaine-crazed negroes" had exchanged their guns for more powerful ones for "the express purpose of combating the 'fiend' when he runs amuck." 2

These were fantastic claims, but Williams was not alone. From the late 19th century to the passage of federal legislation regulating the sale of narcotic drugs in 1914, numerous journals, newspapers, and books from both the North and the South, alleged that growing numbers of black men and some poor whites used cocaine and that black use of cocaine posed a significant threat to the security of whites. News and medical reports frequently depicted black men on cocaine as frenzied, manic, homicidal, lascivious, excitable, criminal, and immoral. They were accused of raping white women, and killing white men. Both southern segregationists and northern doctors urged the government to take strong measures against this dangerous new drug and by 1900 eight states had passed laws prohibiting the dispensing of cocaine without a prescription. By 1915 , every state had passed laws restricting the use of cocaine, while only 36 had passed laws restricting the use of the opiates (opium, morphine and heroin.) ${ }^{3}$ The legal response to cocaine was significantly quicker and more punitive than the response to the opiates. ${ }^{4}$ This article argues that cocaine acquired its reputation as "the most dangerous drug" because of its associations with black men. ${ }^{5}$ It demonstrates how racialization can infuse our images of drugs and their psychotropic effects, a point that is particularly salient in light of more recent controversies over crack cocaine. ${ }^{6}$ Finally, it shows how the issue of regulating 
bodies, especially those of African-Americans and drug users, permeated the progressive era.

Historians of drug use in the United States have long noted that drug use was associated with undesirable minority groups and have argued that this was an important factor behind the passage of laws against drug use. In his important study of legal regulation, David Musto pointed out that blacks were associated with cocaine, the Chinese with smoking opium, and Mexicans with marijuana. John Helmer made racial discrimination the focus of his Marxist analysis of drug legislation, Drugs and Minority Oppression. Denise Herd and Andrew Sinclair have noted that prohibitionists, especially in the South, used the image of the drunken "negro," violent and lascivious, to promote the banning of alcohol. ${ }^{7}$ My contribution to this debate is to argue that beliefs about the people who were perceived to be using the drug helped to determine ideas about the effects of drugs on the body. This is in keeping with a growing literature on drug use that highlights the malleability of ideas about drugs and the purposes to which this flexibility can be put. ${ }^{8}$

Over the past ten years, a variety of scholars have called attention to the impact of constructions of "whiteness" and "blackness" upon Americans' conceptions of themselves and their nation. ${ }^{9}$ Little attention, however, has been paid to the way that the diverse movement of social reform known as Progressivism was racialized. ${ }^{10}$ Historians have long noted that southern progressivism existed alongside the growth of segregation and black disenfranchisment. " In Revolt Against Chivalry Jacqueline Dowd Hall pointed out that: "disenfranchisement and segregation could themselves be seen as seminal progressive reforms, for most white southern progressives welcomed this racial settlement as a means of burying the conflicts of Reconstruction and Populism in order to pursue the goals of public service and social order." 12 The literature on racialization leads to the further conclusion that progressivism's "search for order" was explicitly linked to ideas about race, "civilization," and the need for the discipline and regulation of people who were believed to lack self-control. The construction of "whiteness" and "blackness" in the United States posited a fundamental difference between the abilities of the two races to exert control over the self. Since cocaine, like other psychotropic substances, was thought to pose an additional threat to self-control, it was easy to believe that a) African-Americans were using cocaine, and that b) they were especially dangerous when they did so. Ideas about "blackness" therefore infused ideas about the meanings of cocaine use and led to demands that the use of this drug be controlled by legislation. Additionally, stories of black cocaine use contributed to the idea that African-Americans were less civilized than white Americans and therefore did not deserve the same rights of citizenship.

Coca, the plant from which cocaine is derived, has been used and cultivated in South America for thousands of years. One early chronicler of its use, Garcilaso de la Vega, declared that the magical leaf of the coca plant "satisfies 
the hungry, gives new strength to the weary and exhausted, and makes the unhappy forget their sorrows." ${ }^{13}$ Coca leaves continue to be used today by the rural populations of Peru and Bolivia to relieve hunger and increase stamina. In recent years, cocaine has come under fire as a particularly "addictive" drug. However, most studies show that only a small minority of people who use cocaine (between .5 and $2.5 \%$ ) exhibit compulsive drug seeking behaviour. ${ }^{14}$ Moreover, the whole concept of "addiction," with its assumption of loss of control over the will, rests on the problematic assumption that we all possess a free will that can be compromised by the consumption of mind-altering substances. ${ }^{15}$

Cocaine first became the focus of medical attention in the West when it was isolated from coca in European laboratories between 1855 and $1860 .{ }^{16}$ By 1859 , it was recommended for the relief of toothaches, digestive disorders, neurasthenia and other illnesses. Four years later Angelo Mariani patented a preparation of coca extract and wine, "Vin Mariani," which became one of the most popular prescription medicines of the age. By 1878 , US advertisers were recommending cocaine for "young persons afflicted with timidity in society" and as a "powerful nervous excitant." 17 In the early 1880 s, several doctors suggested that it might prove to be a cure for the opium habit. Cocaine acquired new scientific credibility in 1884 , when Sigmund Freud published the essay that would first bring him academic renown. This paper recommended cocaine for a variety of illnesses, including fatigue, nervousness and neurasthenia. He also praised it as a cure for morphine addiction and for alcoholism. The following month, Freud's friend Karl Koller published a paper describing the anaesthetic properties of cocaine and its usefulness in eye surgery. The use of cocaine as an anaesthetic took off, and until 1899 when Novocain was invented, doctors used it widely as the only available local anaesthetic. ${ }^{18} \mathrm{By}$ the late 1880 s, cocaine was touted as a panacea for hay fever, head colds and "catarrh," a complicated ailment that could include sinusitis, fatigue and indigestion. ${ }^{19}$ William A. Hammond, a former Surgeon General of the United States, suggested it as a cure for stomach irritability, excessive mental exertion, hysteria, and masturbation. ${ }^{20}$

The enthusiasm of physicians for cocaine began to abate when medical periodicals publicized instances of problematic use in the late $19^{\text {th }}$ century. In 1886, medical journals reported cases of cocaine psychosis with tactile hallucinations known as "coke bugs."2l The following year, Freud published "Craving For and Fear of Cocaine" in which he reversed his recommendation of cocaine as cure for opiate addiction, and advised doctors to cease injecting cocaine, although he continued to maintain that it was harmless if taken orally. ${ }^{2}$ Medical professionals quickly acknowledged their responsibility for creating cocaine abusers, and became fairly conservative in their use of the drug. ${ }^{2}$ This paralleled doctors' changing attitudes towards prescribing opiates in the late 19th century, although opiates had been used in medical practice for considerably longer and for a much greater variety of ailments. 
Nonetheless, recreational cocaine use spread in the $1890 \mathrm{~s}$. In the early part of the century, many soda-fountains served cocaine on request. ${ }^{24}$ In 1901 , the Atlanta Constitution reported that cocaine was widely available in soft drinks and over the counter in Mississippi, despite a recent law prohibiting the sale of cocaine without a prescription. ${ }^{\mathrm{x}}$ Numerous soft drinks, including the widelyavailable Coca-Cola contained small amounts of cocaine. ${ }^{26}$ Investigators at Chicago's Hull House in 1904 discovered that cocaine could be bought in saloons, in pool rooms, and on the streets. ${ }^{27}$ Muckraker Samuel Hopkins Adams, the author of a best-selling book on patent medicines, reported in 1906 that cocaine was "distributed in 'samples' at ferries and railway stations" in New York City. He added "you may see the empty boxes and the instructive labels littering the gutters of Broadway any Saturday night, when the drug trade is briskest."28

Many patent medicines also contained cocaine. A 1903 report from the American Pharmaceutical Association indicated that nine tenths of cocainehabitués "have fallen victim to its influence through use of prescriptions or patent medicines containing the drug." ${ }^{29}$ In 1906, when Adams did his research into the patent medicine industry in the United States, he discovered cocaine in a wide variety of catarrh powders. ${ }^{30}$ The most blatant offender, Ryno's Hay Fever-n-Catarrh Remedy, was $99.5 \%$ pure cocaine. ${ }^{31}$ Several asthma remedies such as Az-Ma-Syde and Tucker's Asthma Specific, also contained large amounts of cocaine. ${ }^{\mathcal{W}}$

In 1906, The Pure Food and Drugs Act became law. It required manufacturers to clearly indicate that cocaine was present in their product. Similarly, many local ordinances prohibited the sale of cocaine, but the drug remained widely available in the early part of the century. A government report issued in 1910 indicated that all kinds of advertised remedies for asthma, catarrh colds, coughs, consumption and hay-fever contained cocaine. ${ }^{33}$ In 1911, an article in Hampton's Magazine focused specifically on the threat posed by sodafountain drinks. ${ }^{34} \mathrm{New}$ York journalist Cleveland Moffett examined cases where proprietors had sold cocaine-adulterated soft drinks. None of the convicted went to prison, and none were given large fines. ${ }^{35}$

Nonetheless, soon after the turn of the century, many doctors and journalists claimed that the cocaine habit was more insidious than that of any other drug. ${ }^{36}$ In 1912, C.B. Towns, one of America's leading experts on drug use, stated that "the most harmful of all habit-forming drugs is cocaine. Nothing so deteriorates its victims or provides so short a cut to the insane asylum." 37 In Collier's Magazine, Adams warned that cocaine was "destructive to mind and body alike, and appalling in its breaking down of all moral restraint."38 Cocaine's reputation as the worst of all drugs had much to do with the perception that the "poorest and most depraved classes," especially African-Americans, were using the drug. ${ }^{39}$

The allegations that cocaine was particularly popular among African- 
Americans first appeared in the national press in 1898, when the well-known medical weekly, The Medical News, indicated that blacks had contracted the "cocaine habit" in the port city of New Orleans. "Two years later, The Journal of the American Medical Association related that "The negroes in some parts of the South are reported as being addicted to a new form of vice - that of 'cocain (sic) sniffing' or the 'coke habit."'4l That same year the American Druggist reported that "the newspapers of Georgia, Tennessee and some other Southern States have been printing during the past month some most sensational stories regarding the widespread addiction of the colored and vicious white population of the larger cities to cocaine." ${ }^{, 2}$ The allegations had drifted northward by March, 1903, when a study in The Philadelphia Medical Journal indicated that cocaine use among blacks had spread to northern cities. ${ }^{43}$ By July of that year, The New York Tribune proclaimed that the problem of black cocaine use was so severe that it "threatens to depopulate the Southern States of their colored population." $\mathrm{By}$ 1911, Hampton's Magazine claimed that as many as a million blacks were addicted to cocaine. ${ }^{45}$

Because cocaine use went unmonitored by state authorities, we will probably never know the extent of cocaine use among blacks or whites during this time period. Nonetheless, some significant evidence indicates that the use of cocaine may not have been unusual. Lawrence Levine's study of black music led him to conclude that cocaine use was common. ${ }^{46} \mathrm{Jazz}$ musician Jelly Roll Morton told his biographer that cocaine use was frequent since "you could buy all the dope you wanted in the drug store. Just ask for it and you got it."47 A work song of the day crooned, "Well, the cocaine habit is might' bad,/It kill ev-ybody I know it to have had." 48

Medical officials often claimed that blacks took cocaine to help them perform heavy labour. The British Medical Journal reported that the use of cocaine started among dock workers in New Orleans who found that the drug enabled them to do the difficult work of loading and unloading the boats for up to seventy hours at a stretch, without a rest, in rain or in heat. ${ }^{49}$ The Medical News asserted that cocaine use had spread from dock workers in New Orleans, to Levee Camps in Mississippi, to plantations throughout the South. On many Yazoo plantations, it was said that blacks refused to work unless cocaine was available. ${ }^{50}$ The most detailed description of blacks using cocaine to help them endure difficult working conditions was provided by George E. Pettey in his 1913 book The Narcotic Drug Diseases and Allied Ailments. Pettey indicated that "the power of cocaine to sustain one under a prolonged strain is well understood by the labouring class of negroes. Frequently those engaged in unloading and loading steamers will work forty-eight to sixty hours, continuously, by supporting themselves with cocaine." 51

African-Americans may have been encouraged or forced by employers to take the drug. Dr. Hamilton Wright, a delegate to the United States Opium Commission, conducted a study for the US Senate on this issue, and concluded 
that there was some evidence that "they [contractors] do so under the impression that they can get more and better work from their employees." ${ }^{2}$ Medical News reported that one big planter kept the drug among plantation supplies and issued regular rations of cocaine, just as in the past, he had issued rations of whiskey. ${ }^{53}$ C.B. Towns claimed that overseers "deliberately put cocaine into the rations of his negro laborers in order to get more work out of them."54

Although some employers may have promoted cocaine consumption, the use of cocaine was nonetheless a source of great anxiety for journalists, police chiefs and lawmakers, who feared that cocaine would cause African-Americans to become violent. Observers from a variety of political persuasions blamed cocaine for crime among blacks, although they did so for very different reasons. Colonel C.J. Watson, a Georgia-based commentator in the New York Tribune, stated that: "I am satisfied that many of the horrible crimes committed in the Southern States by the colored people can be traced directly to the cocaine habit." 55 Dr. Hamilton Wright, hoping to gain support from Southern Democrats for drug legislation, told the Senate that "the use of cocaine by the negroes of the South is one of the most elusive and troublesome questions which confront the enforcement of the law in most of the Southern States." 56 Perhaps because it fit in well with his plans for improving African-Americans, Booker T. Washington approvingly quoted a letter from the chief of police of Mobile that asserted: "the chief cause of crime among the Negroes was a lack of necessary education and the excessive use of alcohol combined with the drug habit (cocaine.)"5t

Even blacks without previous records of violence were said to turn into raging criminals under the influence of cocaine. The Medical Record declared that "a large proportion of the wholesale killings in the South during recent years have been the direct result of cocaine, and frequently the perpetrators of these crimes have been hitherto inoffensive, law abiding negroes." 58 .Similarly, a New Orleans newspaper declared, "A pint of the stuff" (a drink cohtaining cocaine) "will transfer (sic) a stupid, good natured negro into a howling maniac." ${ }^{99}$ This suggested that all blacks had within them the innate propensity for crime and created the image that no black could be trusted. Under the influence of cocaine, they might all become murderers. Cocaine, in other words, merely removed the thin veneer of civilisation that prevented the average "negro" from reverting to vicious savagery.

The connection between cocaine and black crime was easy to make since many northerners and southerners already believed that the South was in the grip of a black crime wave. The former U.S. Minister to Russia, and southern Democrat, Clifton R. Breckinridge, argued that there had been an epidemic of crime ever since Reconstruction when blacks were "released from the restraints of law, from personal influence and authority, and actively taught every evil thought and practice." 60 South Carolina Senator Ben Tillman, a leading segregationist, pronounced that: "the poor African has become a fiend, a wild beast, seeking whom he may devour, filling our penitentiaries and our jails."6l 
The idea that black crime and violence was increasing was so pervasive that even black leaders like Harvard Ph.D. W.E.B Dubois felt compelled to state that there was "a distinct class of habitual criminals" among blacks. ${ }^{2}$ A substance like cocaine, which many believed would release blacks' inhibitions, seemed much more frightening in the midst of a black crime wave.

Newspapers and commentators implicated cocaine in many violent attacks. In a letter to a constituent in 1913, Senator Tillman explained that legislation against drugs was necessary since cocaine was "causing so much trouble among the negroes." ${ }^{63}$ That same year, the New York Tribune featured the headline "10 Die in Orgy of Drug-Mad Negroes." Two brothers, Walter and Will Jones, killed three whites and eight blacks, before they were captured and lynched. ${ }^{64}$ The newspaper claimed that a serious race riot was averted only by the arrival of a company of national guardsmen. In New Orleans, in 1900, one of the most serious outbreaks of racial violence since Reconstruction occurred when Robert Charles, a militant black activist, shot a policeman in the leg. When the police arrived at his room just a few hours later, Charles shot and killed two officers, and then escaped. While the police mounted a vast search, mobs began to travel through the city, attacking blacks. After five days of violence in which six blacks were murdered and at least twenty-one were seriously injured, Charles was discovered hiding in a closet just fourteen blocks from his home. Charles killed the two policemen who attempted to take him and took up position at the window of the two-story dwelling, firing on the crowd that had gathered below. He killed another two men, and wounded nineteen others. When Charles dashed for safety he was shot dead ${ }^{65}$ Not surprisingly, both the New Orleans Daily States and Times Democrat asserted that cocaine had been found in his room. ${ }^{66}$

The crime that most concerned white southerners was rape, or "outrages." Observers advanced two reasons for why black men raped white women. The most popular explanation was the black man's "animal instincts" and the "controlling" nature of his "sexual desire."67 Winfield Collins, for example, the author of a book that purported to show that lynchings were the result of black attacks on white women, declared that: "the Negro, child of Africa, but lately removed from the jungle ... has had developed in him by nature, possibly, stronger sexual passion than is to be found in any other race." "When proper restraint is removed" Collins warned, "he gets beyond bounds." Southern novelist and essayist Thomas Nelson Page, another defender of lynching, attributed the growth of rape to carpetbaggers who told blacks that they were the equal of whites and that they should assert their equality. This idea grew gradually, Page continued, "but, when it became widely and deeply rooted, its effect was shown in many ravishings of white women by negroes, sometimes in the presence of the victim's family." 99 Thus rape allegedly had a dual motivation for blacks - first, it was an outlet for blacks' lustful natures, and secondly, it was a way for blacks to express anger at their subservient positions. Social commentators argued that both of these motivations could be unleashed 
by cocaine use.

Sympathetic observers of blacks in the South such as Sir Harry Johnston and the progressive reformer Ray Stannard Baker, believed that cocaine might be responsible for some rapes. Unlike most conservative Southerners, they did not believe that rape was intrinsic to black man's nature. Instead, they blamed cocaine for the rapes that they believed occasionally did occur. Johnston, for example, argued that the Southern states exaggerated blacks' desire for white women and the crimes that were committed under this impulse. ${ }^{70}$ Nonetheless, he asserted that the occasional crimes that took place "were due to the maddening influence of vile whiskey and cocaine snuff." 71 Baker, another opponent of lynching who was skeptical of Southern accusations of rape, admitted that he had been told of two cases of offenses against women in which the "Negro was a victim of the drug habit." 2

Ironically, those who were apt to believe that black men raped white women at every available opportunity, stressed the dangers of cocaine even more strongly. E.H. Williams declared that cocaine increased sexual desire among negroes and that "peaceful negroes became quarrelsome," which in this context appeared to be a euphemism for rape. ${ }^{\mathcal{B}}$ Dr. Christopher Koch declared that: "Most attacks upon white women of the South are the direct result of a cokecrazed negro brain." 74 Even Dr. Hamilton Wright, the Northern anti-drug crusader, hoping to gain southern support for his anti-drug measures, confirmed that cocaine was a "creator of criminals and unusual forms of violence, and it has been a potent incentive in driving the humbler negroes all over the country to abnormal crimes."

Allegations of cocaine use and rape came together in powerful ways in the prelude to the Atlanta riot of 1906. Causes of the riot included an election campaign on black disfranchisement and a labour shortage that was blamed on blacks. But cocaine use was also an influence. That summer, prohibitionist fervour in Georgia had reached messianic heights. The primary focus of the campaign was the perceived danger of allowing black men to drink. Since many whites believed that blacks laced their drinks with cocaine, ${ }^{76}$ giving them courage and fuelling their sexual passions, the two substances were frequently blamed for attacks. On the day the riot began, four assaults were reported, and crowds of blacks and whites began to gather in the city. Around 8:30, on Decatur Street, the notorious vice-district of Atlanta, a man climbed on a platform and worked the crowd into a frenzy, screaming "Save our Women" and "Kill the Niggers!" The crowd destroyed black saloons, pool rooms and restaurants before moving to the black business district. ${ }^{7}$ In the aftermath of the riot, there were renewed calls for prohibition and the saloons were closed for two weeks.

The allegations that cocaine drove black criminals to new heights of crime led to the belief that cocaine itself drove people to violent acts. ${ }^{78}$ Although cocaine reputedly had different effects on whites than on blacks, as we shall see later, cocaine began to acquire a reputation as a criminal-producing drug, 


\section{Left History 7.1}

regardless of the race of individual users. By the early 1910s, leading commentators on drug abuse, such as Pettey, claimed that the cocaine user was liable to turn a pistol or other weapon on an imaginary enemy at any time. "It is never safe," he concluded, "to allow such a person to remain at liberty." "Even earlier, the respected drug expert, Dr. T.D. Crothers, found that: "drugs and spirit takers who come to [my] institution with firearms in their possession are always cocaine takers." ${ }^{100}$ The cocaine user, he continued:

will stoop to any crime, or any act that promises relief, regardless of what the results may be .... The vindictive criminal in lower circles who fights the officer seeking his arrest, who suddenly assaults people on the streets or shoots people without any provocation, or sets fire to buildings, commits serious damages, acts wildly and maniacally, is suffering from cocainism. ${ }^{81}$

By contrast, in an article published twelve years earlier, before the connection between African-Americans and cocaine had been widely publicized, he wrote that the effects of cocaine were "exhilaration" and a "quiet dreamy sleep," but indicated nothing about it producing violence. ${ }^{22}$

Drugs such as opiates were also linked to crime, but usually as a result of people being unable to finance their purchases of the drug. However, cocaine was thought to be criminal-producing by its inherent pharmacological properties. The popular Northern monthly, Hampton's Magazine, noted that crime was not only the result of people stealing money to buy their drug, "but in the frenzy of exhilaration that follows taking it." blacks, cocaine, and crime created the idea that by its very nature, cocaine drove people to crime. Not surprisingly, however, there were no allegations that cocaine caused white men to commit rape. Rape was regarded as a peculiarly black crime, because it purportedly unleashed blacks' much baser sexual desires. $^{84}$

On occasion, medical professionals asserted that the drug had different effects on the two races, leading to greater concern about black cocaine use than white cocaine use. While medical experts claimed that cocaine use led to loss of moral sense and criminality for all users, these accusations were far more acute when they were aimed at black cocaine use. In a typical article, Dr. G.C. Biondi described the effects that cocaine had on white users including paranoid delusions, hallucinations and "exhilaration." However, in the one black user described by Biondi, the drug had a rather different impact, causing "wild, unrestrainable excitement, during the paroxysms of which he would shout, bustle vehemently about, and gesticulate in a menacing mode." 85 In an even more blatant example, physician E.H. Williams stated that: "the first effect produced by cocain [sic] is a mild intoxication. In the negro, however, this intoxication frequently becomes a homicidal frenzy - not the purposeless delirium of the ordinary lunatic, but the cool, calculating, diabolical mania of the fiend." ${ }^{86}$ Similarly, in his article, "The Abuse and Dangers of Cocaine" Dr. W. Scheppergrell stated that the effects of cocaine were "apprehension, delusions, 
and hallucinations" as well as "insomnia, loss of appetite and frequently complete impotence." ${ }^{\prime 77}$ To illustrate the potential danger of the drug he told a moralistic tale about a doctor who lost his practice and was brought to the "brink of ruin" by cocaine. Cocaine use, in this view, was a personal tragedy with serious consequences, but not a criminal matter. Among blacks, however, Scheppergrell deemed cocaine use to be a matter for "police circles." 88 Moreover, Scheppergrell asserted that whites used cocaine to relieve illness while blacks used it "on account of its exhilarating effects." The people who used the drug, therefore determined its effects more than did the drug itself.

The discourse about cocaine use was never exclusively about blacks. Poor whites were also included from time to time, as in E.B. Eberle's statement that cocaine users were most readily found among "the negroes, the lower and immoral classes," or the American Druggist's comment that there was widespread addiction to cocaine among the "colored and vicious white population." 89 There was a tendency at the turn of the century to read "blackness" into whites who were otherwise alienated from the white community. ${ }^{90}$ Morality, in other words, was interpreted in terms of skin colour and certain actions could cause a white person to cross over to blackness. According to Joel Williamson, "by about 1900 it was possible for one who was biologically pure white to become black by behavior." 91 It was therefore not difficult to transfer assumptions about blacks and cocaine use to the lowest classes of whites. ${ }^{92}$

Issues of race and cocaine use could be collapsed in other ways as well. In 1911, a Hampton's Magazine article appeared to suggest that cocaine could actually turn a white person into a black person. "A Woman Victim" of cocaine was described as having "Protruding eye-balls, a thickened nose" and "loose pendulent lips." 93 Similarly, it was common to refer to cocaine users as "slaves" a word that certainly had a colour connotation. These slippages suggested that cocaine was indeed a highly dangerous drug.

Images of drugs and their effects are highly mutable. Even in the period discussed here, the meaning of cocaine use varied depending on who was using the drug and for what purpose. Black drug use in the work setting was given very different meanings from drug use in public spaces. Moreover, while journalists and doctors most often associated cocaine with black men, Mara Keire found that urban reformers in New York and Chicago connected it with prostitutes and "fairies." 94 The association of drug use with "deviant" others had instrumental purposes that extended beyond the demonization of a particular drug. Stories of black cocaine use were part of a larger set of narratives of black male brutality that were used to justify the lynching of black men, disenfranchisement, and the growth of segregation. Examples of cocaine use by "fairies" were part of a campaign to clean up urban vice-districts. In both cases, cocaine acted as a social signifier, representing danger, sexuality, and loss-of-control.

By 1914, medical doctors, southern segregationists, and progressive reformers had all concluded that cocaine was a particularly dangerous drug. 


\section{Left History 7.1}

They based their conclusions less on the actual physical effects of the drug or its addictive potential, than on the people they believed were using the drug. During the period $1890-1914$, a wide variety of social commentators claimed that blacks were morally, spiritually, and mentally inferior. Numerous books and articles accused blacks of being rapists, criminals, and generally shiftless. The identification of blacks as cocaine users at this time therefore had an important impact on changing attitudes towards drug use. Cocaine was a new and little known drug, and it was therefore particularly easy for people to infuse it with new meanings. Since it grew in popularity at the same time as a new view of drug use emerged among medical professionals and among the public at large, it acquired a much more negative reputation than the opiates. The perception that blacks used cocaine, which emerged not long after medical literature first described cocaine addiction, permeated cocaine use with images of violence and criminality. This resulted in stricter laws against cocaine than against the opiates, and led to a new imagery of drug use and drug users, that was tinged with the taint of "blackness," and all the moral failings this represented. A new cultural icon, the "cocainized black," was formed from progressive attitudes towards drugs, and the racial radicalism of the South. This convergence demonstrates how easily racial radicalism and progressivism, with their joint interest in disciplining and controlling bodies, could work hand-in-hand.

I This paper was originally written for a course on African-American history offered by
John Ingham and Michael Wayne. Many thanks are due to John Ingham who
encouraged me to continue working on the paper. John Ingham, Mariana Valverde,
Molly Ladd-Taylor, Franca Iacovetta, Lisa Levenstein, Eva Plach and Robert Wallwork
all provided helpful advice. The comments of the anonymous reviewers helped me
greatly as I revised the paper. The Hannah Institute for the History of Medicine, the
Social Sciences and Humanities Research Council of Canada, and the University of
Toronto provided financial support.
${ }^{2}$ Edward Huntington Williams "Negro Cocaine 'Fiends' Are a New Southern Menace"
New York Times, 8 February, 1914, 12.
3 Martin I. Wilbert "Efforts to Curb the Misuse of Narcotic Drugs" Public Health
Reports, 26 March, 1915, 893-923.
4 By 1912, laws had been passed in forty-four states permitting the dispensing of
cocaine only by prescription. By contrast, only thirty-three states had restricted the
distribution of opiates. Richard J. Bonnie and Charles H. Whitebread II, The Marijuana
Conviction (Charlottesville, Va. 1974 ), 15. A state-by-state review published in Public
Health Reports in 1915, shows that 12 states which had laws against cocaine, had no
laws against the opiates. Others had laws against cocaine which were much more severe
than legislation against the opiates and other drugs. States which had more severe law
against cocaine included many states with a high percentage of African-Americans
including: Arkansas, Louisiana, Mississippi, Missouri, South Carolina, and Virginia.
Wilbert, "Efforts to Curb," $893-923$.
5 Historians of drug laws in the United States have long recognized the connections that 
were drawn between blacks and cocaine. However, they have not drawn attention to the fact that the association of blacks with cocaine use created new images of cocaine and its effects. They have also not drawn on the literature of race-relations to explain why this connection worked so effectively. David Musto, The American Disease: The Origins of Narcotic Control (New Haven 1973); David Courtwright, Dark Paradise: Opiate Addiction in America before 1940 (Cambridge Mass. 1982); David Courtwright, "The Hidden Epidemic: Opiate Addiction and Cocaine Use in the South, 1860-1920, in "The Journal of Southern History 49(1), February, 1983, 57-72; Joel Phillips and Ronald W. Wynne, Cocaine: The Mystique and the Reality (New York 1980); Lester Grinspoon and James Bakalar, Cocaine: A Drug and Its Social Evolution (New York 1985); John Helmer and Thomas Vietorisz, Drug Use, the Labor Market and Class Conflict (Washington DC. 1974); John Helmer, Drugs and Minority Oppression (New York 1975); Gerald McLaughlin, "Cocaine: The History and Regulation of a Dangerous Drug" Cornell Law Review (58), February, 1973, 537-577; Jill Jonnes, Hep-Cats, Narcs, and Pipe Dreams: A History of America's Romance with Illegal Drugs (New York 1986).

${ }^{6}$ See Craig Reinarman and Harry G. Levine, Crack in America: Demon Drugs and Social Justice (Berkeley 1997).

${ }^{7}$ Denise Herd, "We Cannot Stagger to Freedom: A History of Blacks and Alcohol and in American Politics" in Leon Brill and Charles Winick, eds., The Yearbook of Substance Use and Abuse Volume 3 (New York 1985), 141-188; Denise Herd, "The Paradox of Temperance: Blacks and the Alcohol Question in Nineteenth-Century America" in Susanna Barrows and Robin Room, eds., Drinking: Behavior and Belief in Modern History (Berkeley 1991), 354-375; Andrew Sinclair, Prohibition: The Era of Excess (London 1962), 48-52.

${ }^{8}$ One of the first works to recognize that ideas about drugs are shaped by social beliefs was Thomas Szasz, Ceremonial Chemistry: The Ritual Persecution of Drugs, Addicts and Pushers (Garden City, N.Y. 1974). Recent collections on drug use have also employed a more cultural approach: Jordan Goodman, Paul E. Lovejoy and Andrew Sherrat, eds., Consuming Habits: Drugs in History and Anthropology (London 1995); Roy Porter and Mikulas Teich, eds., Drugs and Narcotics in History (Cambridge, UK 1995), Ross Coomber, ed. The Control of Drugs and Drug Users (Amsterdam 1998). See also Dawn Moore and Mariana Valverde, "Maidens at Risk: 'Date Rape Drugs'And the Formation of Hybrid Risk Knowledges," Economy and Society (forthcoming).

${ }^{9}$ David Roediger, The Wages of Whiteness: Race and the Making of the American Working Class (New York 1991); Grace Elizabeth Hale, Making Whiteness: The Culture of Segregation in the South 1890-1940 (New York 1998); Robin Kelley, Race Rebels: Culture, Politics and the Black Working Class (New York 1994); bell hooks, Black Looks: Race and Representation (Toronto 1992).

${ }^{10}$ There is a vast literature on progressivism. See Paul Boyer, Urban Masses and Moral Order in America, 1820-1920 (Cambridge, Mass. 1978); Robert H. Weibe, The Search for Order 1877-1920 (New York 1967); John Dittmer, Black Georgia in the Progressive Era 1900-1920 (Urbana 1977); Dewey Grantham, "The Countours of Southern Progressivism” American Historical Review 86(5) December 1981, 1035-1059; Arthur S. Link, "The Progressive Movement in the South 1870-1914" North Carolina Historical Review 23(2) 1946, 172-195. The best discussion of the racialization of turnof-the-century reform movements, albeit in a Canadian context, is Mariana Valverde, 
The Age of Light, Soap and Water: Moral Reform in English Canada, 1885-1925 (Toronto 1991). Kevin J. Mumford also provides a discussion of the severe racism of progressivism in his book Interzones: Black/White Sex Districts in Chicago and New York in the Early Twentieth Century (New York 1997).

II William A. Link, The Paradox of Southern Progressivism (Chapel Hill 1992), 70.

12 Jacqueline Dowd Hall, The Revolt Against Chivalry: Jessie Damiel Ames and the Women's Campaign Against Lynching (New York 1979), 55.

${ }^{13}$ Grinspoon and Bakalar, Cocaine, 9.

${ }^{14}$ See: Patricia G. Erickson and Bruce Alexander, "Cocaine and Addictive Liability," Social Pharmacology 3(3), 249-270 This article is a review of the literature on the addiction liability of cocaine. For another extensive review of the literature on cocaine see Bruce Alexander, Peaceful Measures: Canada's Way out of the "War on Drugs" (Toronto 1990), 167-216. A fascinating description of how definitions of cocaine's addictive liability have changed over time can be found in Ronald Akers, "Addiction: The Troublesome Concept," The Journal of Drug Issues 21(4) 1991, 777-793.

15 Mariana Valverde, Diseases of the Will: Alcohol and the Dilemmas of Freedom (Cambridge 1998).

${ }^{16}$ There is some disagreement over who was actually responsible for isolating cocaine. In Patricia Erickson et al., The Steel Drug: Cocaine in Perspective (Lexington and Toronto 1987). It is claimed that cocaine was isolated in 1860 by Albert Niemann. (3) Grinspoon and Bakalar declare that it was a gradual process with the first breakthrough coming in 1855 by Gaedecke, and the final achievement occurring in 1860 by Niemann. Grinspoon and Bakalar, Cocaine, 19.

${ }^{17}$ Grinspoon and Bakalar, Cocaine, 20.

${ }^{18}$ Ibid., 22-23; Alexander, Peaceful Measures, 171-174.

${ }^{19}$ Samuel Hopkins Adams described catarrh as: "Whatever ails you. ... Pneumonia is catarrh of the lungs; so is consumption. Dyspepsia is catarrh of the stomach. Enteritis is catarrh of the intestines..." Samuel Hopkins Adams, Great American Fraud (Chicago 1912).

${ }^{2}$ William A. Hammond, "Coca: Its Preparations and Their Therapeutical Qualities with Some Remarks on the So-Called 'Cocaine Habit," Transactions of the Medical Society of Virginia, November 1887, 225.

${ }^{21}$ Grinspoon and Bakalar, Cocaine, 29.

${ }^{2}$ Alexander, Peaceful Measures, 172.

${ }^{2}$ Spillane, Cocaine, 63-131.

${ }^{24}$ E.B. Eberle, "Report of the Committee on the Acquirement of Drug Habits" American Journal of Pharmacy 75, (October 1903), 483.

$\gamma$ "Cocaine is Sold Illegally," Atlanta Constitution, 20 November, 1901, 5.

${ }^{26}$ Coca-Cola removed all cocaine from its product in 1903. In 1891, Asa Candler, the head of Coca-Cola claimed that the formula called for a half ounce of coca leaf per gallon of syrup. However, the original formula called for ten times as much. Mark Pendergrass, For God, Country and Coca-Cola (New York 1993), 59-60; and Frederick Allen, Secret Formula (New York 1994), 47-48; Joseph Spillane asserts that CocaCola's national competitors had approximately 2 milligrams of cocaine in a 6 ounce glass. Since many soda-fountains increased the syrup portion by as much as $100 \%$ the typical dose may have been somewhat higher. See Joseph Spillane, "Making a Modern Drug: The Manufacture, Sale, and Control of Cocaine in the United States 1880-1920," 
in Paul Gootenberg, ed., Cocaine: Global Histories (London 1999), 25.

27 "The Hull House War on Cocaine," Charities and the Commons, 17 March, 1907, 1034.

28 Adams, Great American Fraud, 42. Adams' articles in Collier's Magazine were instrumental in the passage of the 1906 Pure Food and Drug Act.

${ }^{29}$ Eberle, "Report," 485.

30 "Snuffing Out the Cocaine Fiend," The Common Welfare, 13 April, 1907, 73.

${ }^{31}$ Phillips and Wynne, Cocaine, 49-50.

32 Joseph Spillane, Cocaine: From Medical Marvel to Modern Menace in the United States 1884-1920 (Baltimore 2000), 85-98.

33 "Habit Forming Drugs," The Independent, 18 May, 1911, 1077.

${ }^{34}$ Cleveland Moffett, "Rapid Increase of the Most Dangerous Drug Habit," Hampton's Magazine 26 May, 1911, 595-606.

${ }^{35}$ Ibid., 605.

36 "The Growing Menace of the Use of Cocaine," New York Times, 2 August 1908, 1; "Habit Forming Drugs," The Independent, 18 May 1911, 1077; Dr. Wm F. Boos, "From a Physicians Point of View: The Dope Evil" reprinted in Gerald Grob, ed., American Perceptions of Drug Addiction: Five Studies 1872-1912 (New York 1981), 191.

${ }^{37}$ C.B. Towns, "Peril of the Drug Habit," Century Magazine (84), 1912, 586.

${ }^{38}$ Adams, Great American Fraud, 42.

39 "Growing Menace of the Use of Cocaine," 1.

W. Scheppergrell, "The Abuse and Dangers of Cocaine," The Medical News, 1 October, 1898, 421.

41 "The Cocain Habit," Journal of the American Medical Association, 23 June, 1900, 1637.

Q “Cocaine Alley," American Druggist 37, 10 December, 1900, 337.

4 Thomas G. Simonton, "The Increase of the Use of Cocaine Among the Laity in Pittsburg," The Philadelphia Medical Journal, 28 March, 1903, 556.

44 "Cocaine Sniffers," New York Tribune, 27 June, 1903, 11.

45 Moffett, "Rapid Increase," 599.

${ }^{46}$ Courtwright, Dark Paradise, 200.

${ }^{47}$ Lomax, Mister Jelly Roll (New York 1950), 50 (quoted in William Ivy Hair, Carnival of Fury: Robert Charles and the New Orleans Race Riot of 1900 [Baton Rouge 1976], 76).

48 Lawrence Levine, Black Culture and Black Consciousness (Oxford 1977), 283.

49 "The Cocaine Habit Among Negroes," British Medical Journal, 29 November, 1902. 50 "Negro Cocaine Fiends," Medical News, 8 November, 1902, 895.

${ }^{51}$ George E. Pettey, The Narcotic Drug Diseases and Allied Ailments (New York [1913] 1981), 426. Progressive muckraker Ray Stannard Baker also repeated the story of an eighteen-year-old black who left his plantation to work in a railroad camp where he learned to use cocaine. Baker, Following the Color Line: American Negro Citizenship in the Progressive Era (New York [1908] 1964), 89.

$\checkmark$ Hamilton Wright, "Report on the Opium Problem," (1910) U.S. Senate, 61st Congress, 2nd Session, Document \#377, 49.

53 "Negro Cocaine Fiends," Medical News, 8 November, 1902, 895.

${ }^{54}$ C.B. Towns, "Peril of the Drug Habit," 586.

55 "Cocaine Sniffers," New York Tribune, 27 June, 1905, 11. 


\section{Left History 7.1}

${ }^{56}$ Hamilton Wright, "Report," 49.

${ }^{57}$ Booker T. Washington, "Negro Crime and Strong Drink," Journal of Criminal Law, 1912-13, 385.

${ }^{\$ 8}$ E. H. Williams, "The Drug Habit Menace in the South," Medical Record (85), 7 February, 1914, 247.

${ }^{99}$ New Orleans Times Democrat, 31 October, 1900. Quoted in Hair, Carnival of Fury, 76.

${ }^{6}$ Race Problems of the South: Report of the Proceedings of the First Annual Conference Held Under the Auspices of the Southern Society for the Promotion of the Study of Race Conditions and Problems in the South (New York 1969, c. 1900), 174.

${ }^{61}$ Albert Bushnell Hart, The Southern South (New York 1910), 93.

${ }^{2}$ W.E.B. Dubois, The Philadelphia Negro (New York 1899), 259.

${ }^{63}$ B. R. Tillman to Dr. W.A. Ross, October 6, 1913, Benjamin Ryan Tillman Papers, Clemson University, Clemson, S.C. quoted in Joel Williamson The Crucible of Race (New York 1984), 210.

64 "10 Die in Orgy of Drug-Mad Negroes," New York Tribune, 29 September 1913, 1.

${ }^{6}$ Williamson, The Crucible of Race, 201-209; Hair, Carnival of Fury.

"Hair, Carnival of Fury, 132.

67 "Some Fresh Suggestions about the New Negro Crime," Harper's Weekly (48), 23 January, 1904, 121.

${ }^{B}$ Winfield H. Collins, The Truth About Lynching and the Negro in the South (New York 1918), 58.

$\theta 9$ "Some Fresh Suggestions about the New Negro Crime," 120.

${ }^{7}$ Sir Harry Johnston, The Negro in the New World (London 1910), 482.

71 Ibid., 463.

72 Baker, Following the Color Line, 47.

${ }^{73}$ Williams, "The Drug-Habit Menace in the South," Medical Record (85), 7 February, $1914,247$.

74 “This Drug-Endangered Nation" The Literary Digest, 23 March 1914, 687.

$7^{5}$ Hamilton Wright, "Report," 51.

${ }^{*}$ See for example: Ibid., 49.

7 Williamson, The Crucible of Race, 209-220.

7 Spillane argues that connections between cocaine and violence preceded cocaine's association with blacks (Dark Paradise, 314). However, the associations between cocaine and violence took on a whole new tenor and intensity in the early twentieth century.

${ }^{7}$ Pettey, Narcotic Drug, 426-27.

${ }^{8}$ T.D. Crothers, "Cocainism," Quarterly Journal of Inebriety, 1910, 79.

81 lbid., 80.

82 T.D. Crothers, “Cocaine-Inebriety," Quarterly Journal of Inebriety, 1898, 370.

83 Moffett, "Rapid Increase," 604.

84 Jacquelyn Dowd Hall, "The Mind that Burns in Each Body': Women, Rape and Racial Violence" in Ann Snitow, Christine Stansell and Sharon Thompson, eds., Powers of Desire (New York 1983), 337.

85 "A Few Remarks on Cocainism," American Medicine, September, 1911, 468.

\$ Williams, "Prohibition from the Medical Standpoint," 276-277.

${ }^{87}$ Scheppergrell, "The Abuse and Dangers of Cocain," 420. 
"The Most Dangerous Drug" 61

8 Ibid., 421.

${ }^{9}$ Eberle, "Report," 480; “Cocaine Alley," 337.

90 See the growing literature on the construction of "whiteness," and in particular David Roediger, The Wages of Whiteness.

${ }^{91}$ Williamson, The Crucible of Race, 465-7.

92 Warren Hedges, "If Uncle Tom is White, Should we Call Him Auntie?: Race and Sexuality in Post-Bellum U.S. Fiction," in Mike Hill, ed., Whiteness: A Critical Reader (New York 1997).

${ }^{9}$ Moffett, "Rapid Increase," 596.

94 Mara Keire, "Dope Fiends and Degenerates: The Gendering of Addiction in the Early Twentieth Century" Social History 31(4), Summer, 1998, 809-822. 